\title{
ANALISIS SCP KOMODITAS PANGAN KOTA TARAKAN
}

\section{SCP ANALYSIS IN TARAKAN CITY}

\author{
Retno Dwi Arini' ${ }^{1}$ Sulistya Rini Pratiwi ${ }^{2}$ \\ ${ }^{1}$ Sekolah Tinggi Ilmu Ekonomi Bulungan Tarakan \\ ${ }^{2}$ Jurusan Ekonomi Pembangunan, Fakultas Ekonomi Universitas Borneo Tarakan \\ sr.pratiwi@borneo.ac.id
}

\begin{abstract}
Abstrak: Tujuan dari penelitian ini adalah menganalisis struktur pasar komoditas pangan yang dihasilkan Kota Tarakan sehingga diperoleh gambaran pola distribusi dari komoditas pangan. Alat analisis yang digunakan adalah Concentration ratio (CR), Minimum Efficiency Scale (MES) dan Price Cost Margin (PCM). Hasil analisis menunjukkan bahwa pasar komoditi pangan yang dihasilkan Kota Tarakan, dalam hal ini adalah cabe rawit, cabe merah, daging ayam ras segar, ikan bandeng dan telur ayam ras, menunjukkan pada stuktur pasar persaingan tidak sempurna. Hal ini mengindikasikan bahwa harga-harga komoditas relatif mahal.
\end{abstract}

Kata Kunci: CR, MES, PCM, Komoditas Pangan.

Abstract : The purpose of this study was to analyze the market structure of food commodities produced in the City of Tarakan, in order to obtain an overview of the food commodities distribution patterns. The analysis tools used were Concentration Ratio (CR), Minimum Efficiency Scale (MES) and Price Cost Margin (PCM). The analysis result showed that the food commodity market produced in the City of Tarakan, in this case were cayenne pepper, red chilies, fresh broiler chicken, milkfish and eggs were the imperfect competition market structure. This indicated that commodity prices were relatively expensive.

Keywords: CR, MES, PCM, Food Commodities.

\section{PENDAHULUAN}

Pembangunan ekonomi daerah adalah suatu proses yang mencakup pembentukan institusi-institusi baru, pembangunan industri-industri alternatif, perbaikan kapasitas tenaga kerja yang ada untuk menghasilkan produk dan jasa yang lebih baik, identifikasi pasar-pasar baru, ahli ilmu pengetahuan dan pengembangan perusahaan perusahaan baru (Cristea, 2014). 
Pengembangan metode yang menganalisis perekonomian suatu daerah penting sekali kegunaannya untuk mengumpulkan data tentang perekonomian daerah yang bersangkutan serta proses pertumbuhannya, yang kemudian dapat dipakai sebagai pedoman untuk menentukan tindakan-tindakan apa yang harus diambil untuk laju pertumbuhan yang ada (Chirwa \& Odhiambo, 2016). Namun di pihak lain harus diakui bahwa menganalisis perekonomian suatu daerah sangat sulit karena Data tentang daerah sangat terbatas terutama kalau daerah dibedakan berdasarkan pengertian daerah modal. Dengan data yang sangat terbatas sangat sukar untuk menggunakan metode yang telah dikembangkan dalam memberikan gambaran mengenai perekonomian suatu daerah.

Data yang tersedia umumnya tidak sesuai dengan data yang dibutuhkan untuk analisis daerah, karena data yang terkumpul biasanya ditujukan untuk memenuhi kebutuhan analisis perekonomian secara nasional. Data tentang perekonomian daerah sangat sukar dikumpulkan, sebab perekonomian daerah lebih terbuka dibandingkan dengan perekonomian nasional. Hal tersebut menyebabkan data tentang aliran-aliran yang masuk dan keluar dari suatu daerah sukar diperoleh.

Jumlah penduduk akan mempengaruhi tingkat harga suatu barang atau jasa. Sebagaimana yang diketahui bahwa penyebab inflasi salah satunya berasal dari permintaan yang tinggi (Mishkin, 1984). Dalam hal ini meningkatnya jumlah penduduk di Kota Tarakan maka akan mempengaruhi tingginya permintaan barang di Kota Tarakan. Namun, jumlah penduduk hanya merupakan salah satu faktor yang menyebabkan jumlah permintaan suatu barang meningkat sehingga harga-harga barang naik (inflasi). Oleh sebab itu, jumlah penduduk bukan faktor utama yang secara langsung mempengaruhi naiknya harga suatu barang atau jasa (Gavin \& Mandal, 2002).

Peningkatan harga komoditas pangan memang dapat berasal dari produsen, namun sumber peningkatan harga tersebut biasanya lebih bersifat fundamental karena di dorong oleh meningkatnya harga input/sarana produksi atau karena faktor kebijakan pemerintah seperti penetapan harga dasar (floor price). Sementara peningkatan harga yang didorong oleh faktor distribusi bersifat variabel, seperti panjangnya rantai jalur distribusi, hambatan transportasi dan perilaku pedagang dalam: menetapkan marjin keuntungan, aksi spekulasi maupun kompetisi antar pedagang.

Tingginya volatilitas harga komoditas yang terjadi selama ini mengindikasikan bahwa faktor distribusi sangat berpengaruh $(\mathrm{Hu}$, M., Zhang, D., Ji, Q., \& Wei, L., 2020). Maka tujuan penelitian ini 
adalah memperoleh gambaran pola distribusi dari komoditas pangan. Dari studi ini diharapkan akan diperoleh pemahaman yang lebih baik tentang pengaruh perbedaan karakteristik pada komoditas pangan tersebut.

\section{TINJAUAN PUSTAKA}

Permintaan dan Penawaran

Keinginan seseorang (konsumen) terhadap barang-barang tertentu yang diperlukan atau diinginkan. Namun dalam praktik, pengertian permintaan seperti ini menunjukkan adanya permintaan atas sejumlah barang dan jasa yang diikuti dengan kemampuan membeli (purchasing power). Karena bila keinginan (wants) diikuti dengan kekuatan untuk melakukan pembelian (purchasing power), maka keinginan (wants) akan berubah menjadi permintaan, jadi:

Demand $=$ Wants + Purchasing Power

$\begin{array}{lrr} & \text { Permintaan (demand) sebagai } \\ \text { suatu } & \text { konsep } & \text { mengandung } \\ \text { pengertian } \quad \text { bahwa } & \text { permintaan }\end{array}$ berlaku terhadap tiga variabel ang saling mempengaruhi, yaitu: kualitas produk barang atau jasa (product quality), harga (price), manfaat produk barang atau jasa tersebut (product benefit) yang sangat mempengaruhi konsumen dalam melakukan pembelian kebutuhannya. Dalam ilmu ekonomi, hukum permintaan mengatakan bahwa terjadi pengaruh timbal balik antara barang yang diminta dengan harga, jika faktor lain tidak mengalami perubahan (ceteris paribus) Dalam hal ini, hukum permintaan mengatakan: "Bila harga suatu barang dan jasa naik, sedangkan harga barang-barang dan jasa lainnya tetap sama, maka konsumen cenderung melakukan subtitusi, menggantikan barang atau jasa yang harganya naik dengan brang yang lain (yang mempunyai fungsi sama) yang harganya relatif lebih murah. Terbentur pada kenyataan-kenyataan yang ada dan akhirnya menimbulkan pertanyaan seputar perilaku konsumen akan munculnya 'ketidak logisan' konsumen dalam memenuhi kebutuhannya tersebut membuat para pakar ekonomi pariwisata melakukan studi yang mengupayakan munculnya keseimbangan antara permintaan dan penawaran terkait perilaku konsumen tersebut, atau dalam istilah ekonomi disebut pendekatan "consumer market approach". Penelitian tentang permintaan ini sebenarnya merupakan suatu perkembangan baru, dimana pada mulanya para ahli ekonomi dulunya hanya memperhatikan faktor penawaran (supply) saja, kini juga mempelajari faktor/ sisi permintaan (demand) untuk menjawab 'ketidak logisan' dari perilaku konsumen yang ada (Yoeti, 2008).

Sama halnya dengan hukum permintaan, variabel-variabel lain disamping harga dapat menentukan 
jumlah suatu barang atau jasa yang ditawarkan. Hukum penawaran biasanya digambarkan dalam bentuk grafik sebagai kurva penawaran yang berbanding lurus antara variabel horisontal dan variabel vertikalnya.

Kepuasan konsumen akan tercapai apabila semua uang yang dibelanjakan untuk kebutuhannya dapat memberi kepuasan sesuai dengan apa yang diinginkan atau diimpikannya. Jadi, ada pengaruh timbal balik antara permintaan (demand) dan harga (price) di pihak lain. Bila harga suatu barang dan jasa naik, sedangkan harga barang-barang dan jasa lainnya tetap sama, maka konsumen cenderung melakukan subtitusi, menggantikan barang atau jasa yang harganya naik dengan barang yang lain (yang mempunyai fungsi sama) yang harganya relatif lebih murah.

Adapun harga atau biaya
yang diinginkan konsumen
(wisatawan) akan terbentuk bila
tingkat harga yang diinginkan sama
dengan tingkat kepuasan dari
konsumen tersebut akan produk yang
ditawarkan. Dalam kata lain terjadi
kesimbangan antra permintaan dan
penawaran yang ditunjukkan dengan
nama Equilibrium. Titik bertemunya
kurva permintaan dan kurva
penawaran. Keseimbangan
penawaran dan permintaan dikatakan
stasioner dalam arti bahwa sekali
harga keseimbangan tercapai,
biasanya cenderung untuk tetap dan

tidak berubah selama permintaan dan penawaran tidak berubah.

\section{Struktur Pasar}

Struktur adalah susunan bagian-bagian dalam suatu bentuk bangunan. Struktur pasar dalam suatu industri yang mengindikasikan derajad persaingan dalam industri. Struktur pasar dalam industri cenderung berubah secara perlahanlahan, bahkan dapat dianggap tetap atau relatif permanen dalam jangka pendek. Struktur dalam industri, setidaknya, terkait dengan beberapa hal berikut, seberapa tinggi derajad konsentrasi penjual, seberapa tinggi derajad konsentrasi pembeli, seberapa tunggi derajad diferensiasi produk, dan seberapa tinggi tingkat kesulitan yang ditemui oleh perusahaan baru untuk masuk kedalam suatu industri. Struktur pasar merupakan elemen strategis yang relatif permanen dari lingkungan perusahaan yang mempengaruhi dan dipengaruhi oleh perilaku dan kinerja di dalam pasar. Struktur pasar adalah bahasan yang penting untuk mengetahui perilaku dan kinerja industry (Kuncoro, 2007).

Struktur pasar terdiri atas (5) unsur: (1) Jumlah dan besarnya distribusi penjual; (2) Jumlah dan besarnya distribusi pembeli; (3) Diferensiasi produk; (4) Halangan memasuki pasar; (5) Struktur biaya; (6) Integrasi vertikal;

Konglomerasi. 
Unsur pertama adalah jumlah dan besarnya distribusi penjual, Pada pasar persaingan sempurna terdapat banyak penjual, dimana tidak ada satupun perusahaan yang dapat mempengaruhi harga. Perusahaan di pasar persaingan sempurna akan menawarkan produknya dengan harga sama dengan opportunity cost untuk memproduksinya $(\mathrm{P}=\mathrm{MC})$. Untuk memaksimalkan keuntungan, perusahaan akan memilih output optimal pada saat MR $=$ MC. Profit perusahaan pada pasar persaingan sempurna, tergantung pada average cost (AC).

Unsur kedua adalah jumlah dan besarnya distribusi pembeli. Jumlah dan besarnya pembeli berpengaruh terhadap struktur pasar. Pada industri mebel jumlah pembeli cukup besar sehingga kecil kemungkinan pembeli dapat mengatur harga, namun pada produk yang dibuat atas dasar pesanan (by order) dalam kuantitas yang besar dan berkelanjutan, pembeli dapat menekan harga penjual.

Unsur ketiga adalah deferensiasi. Pada pasar persaingan sempurna, produk yang dijual adalah homogen, sehingga tidak mengenal deferensiasi. Deferensiasi produk terjadi pada struktur pasar persaingan monopolistik, pasar oligopoli dan pasar monopoli. Deferensiasi bisa terjadi pada kualitas produk yang sama tetapi berbeda warna, rasa dan lainnya, atau jenis produk yang sama tetapi kualitasnya yang berbeda.
Deferensiasi produk dapat menciptakan market power, sehingga dapat menurunkan intensitas persaingan (Arsyad, 2014).

Unsur keempat adalah halangan memasuki pasar. Hambatan pasar dapat diartikan sebagai hambatan masuk industri, yaitu kondisi dimana perusahaan potensial yang akan atau baru masuk ke dalam suatu industri (new entrants) mengalami kesulitan karena tidak memiliki banyak keunggulan kompetitif sebagaimana dimiliki perusahaan yang sudah ada sebelumnya dalam industri tersebut (existing firms). Fenomena ini dapat terjadi karena faktor alamiah (seperti perbedaan akses teknologi yang digunakan dalam proses produksi atau perbedaan struktur biaya antar perusahaan dalam industri) maupun faktor non-alamiah (seperti berbagai tindakan existing firms yang dirancang untuk mencegah atau menghalangi new entranst untuk bisa masuk ke dalam industridan kebijakan pemerintah).

\section{Structure-Conduct-Performance (SCP)}

Hoskins.dkk

(2004)

mengemukakan 3 kerangka analisis yang dapat menjelaskan berbagai sisi kerja bisnis media. Ketiga kerangka tersebut sekaligus merupakan indikator yang cukup relevan untuk menilai karakteristik industri media karena menyajikan informasi pokok terkait dengan keunikan operasi 
bisnis media massa. Ketiga kerangka analisis yang dimaksud meliputi strukturekonomi (structure), operasio nalisasi perusahaan (conduct), dan kinerjaperusahaan (performance). Pe ndekatan SCP sendiri pertama kali diperkenalkan oleh Mason (1939) yang kemudian diaplikasikan oleh Bain (1951) melalui studi lintas disiplin (Wirth dan Bloch, 1995). Esensi pendekatan SCP terhadap analisis organisasi industri adalah adanya hipotesis yang menyatakan bahwaperformance atau keberadaan pasar (atau industri) dipengaruhi oleh perilaku perusahaan dalam pasar, sedangkan perusahaan dipengaruhi pula oleh berbagai variabel yang membentuk struktur pasar (Wirth dan Bloch, 1995). Dalam struktur pasar terdapat tiga elemen pokok yaitu pangsa pasar (market share), konsentrasi pasar (market concentration) dan hambatan-hambatan untuk masuk pasar (barrier to entry). Perspektif dalam paradigma SCP adalah bahwa struktur industri akan mempengaruhi perilaku pelaku usaha, dan selanjutnya interaksi antara struktur dan perilaku pengusaha akan berdampak pada kinerja (performance) industri (Mishra \& Vikas, 2010).

Untuk mengukur struktur pasar dapat digunakan beberapa ukuran yaitu rasio konsentrasi dan Minimum Efficiency of Scale (MES) (Kadir dkk, 2020). Struktur sebuah pasar akan mempengaruhi perilaku perusahaan dalam pasar tersebut yang secara bersama-sama menentukan kinerja sistem pasar secara keseluruhan. Kinerja suatu industri diukur antara lain dari derajat inovasi, efisiensi dan profitabilitas. Dalam struktur pasar terdapat tiga elemen pokok yaitu pangsa pasar (market share), konsentrasi pasar (market contcentration) dan hambatanhambatan untuk masuk pasar (barrier to entry).

Pangsa pasar (market share) adalah persentase pasar yang ditentukan dalam ukuran unit maupun revenue dan dihitung berdasarkan spesific entity, disebut juga sebagai indikator tentang apa yang dilakukan oleh sebuah perusahaan terhadap kompetitornya dengan dukungan perubahan dalam sales (Panagiotou, 2006). Berdasarkan dari pangsa pasar, konsentrasi pasar dan hambatanhambatan masuk pasar maka struktur pasar dapat ditentukan dengan pendekatan rasio konsentrasi yaitu CR4 (Concentration Ratio for The Bighest Four). Menurut Cramer (2009), CR4 merupakan penjumlahan pangsa pasar empat perusahaan terbesar dari suatu wilayah pasar.

Salah satu indikator yang digunakan untuk menganalisis kinerja pasar adalah melalui perolehan keuntungan dalam industri. Namun data mengenai keuntungan perusahaan tidak dapat 
dipublikasikan. Untuk mengganti data keuntungan perusahaan maka digunakan Price Cost Margin $(P C M)$ sebagai proksi keuntungan dari pasar, Efisiensi internal (XEff) menunjukan tingkat efisiensi suatu industri dalam meminimalisasi biaya produksi dan Growth yang menggambarkan pertumbuhan produk industri dari tahun ke tahun. Kinerja pasar merupakan indikator kritis tentang bagaimana sebaiknya aktivitas pemasaran dari petani atau pedagang yang dikonsentrasikan untuk kesejahteraan umum. Analisis PCM digunakan untuk menganalisis hubungan struktur pasar terhadap kinerja perusahaan.

\section{METODOLOGI PENELITIAN}

Penelitian ini dilakukan di Kota Tarakan, dengan menggunakan data primer dan data sekunder. Data diperoleh dari hasil wawancara pada para pedagang komoditas pangan. Studi ini memfokuskan pada beberapa komoditas pangan yang memiliki peran besar dalam pembentukan inflasi secara nasional (volatile foods). Dan sebagian besar dihasilkan di Kota Tarakan, yaitu cabe merah, cabe rawit beras, daging ayam ras segar, ikan bandeng dan telur ayam ras (BPS, 2019). Alat analisis yang digunakan adalah Analisis Rasio Konsentrasi/ CR4 (Cramer, 2009), Minimum Efficiency of Scale / MES (Curry \& George,
1983) dan Price Cost Margin / PCM (Liebowitz, 1982).

\section{HASIL DAN PEMBAHASAN}

Berdasarkan dari pangsa
pasar komoditi pangan yang
dihasilkan Kota Tarakan, konsentrasi
pasar dan hambatan-hambatan masuk
pasar maka struktur pasar ditentukan
dengan CR4 (Concentration Ratio
for The Bighest Four).

Tabel 1 Analisis Structure-ConductPerformance (SCP) Komoditi

\begin{tabular}{|l|c|c|c|}
\hline \multicolumn{1}{|c|}{ Komoditi } & CR 4 & MES & PCM \\
\hline Cabai Merah & 0.99 & 0.99 & 0.94 \\
\hline Cabai Rawit & 1.00 & 1.00 & 0.88 \\
\hline $\begin{array}{l}\text { Daging Ayam } \\
\text { Ras }\end{array}$ & 1.00 & 1.00 & 0.37 \\
\hline Ikan Bandeng & 1.00 & 1.00 & 0.92 \\
\hline $\begin{array}{l}\text { Telur Ayam } \\
\text { Ras }\end{array}$ & 0.99 & 0.99 & 0.99 \\
\hline
\end{tabular}

Sumber: Data diolah, 2019

Berdasarkan hasil perhitungan didapatkan nilai CR4 yang dijelaskan pada tabel 1. secara keseluruhan pasa komoditi di Kota Tarakan memiliki nilai CR4 (tingkat konsentrasi) diatas 70\%. Hal ini menunjukkan bahwa ada pasar komoditi di Kota Tarakan memiliki struktur pasar very high oligopoly. Artinya konsentrasi 4 pedagang terbesar menguasai 100 persen pangsa pasar komoditi. Rasio Konsentrasi yang tinggi menunjukkan bahwa sebagian besar pangsa pasar dikuasai oleh sejumlah kecil perusahaan. Dengan demikian, 
persaingan dalam pasar tersebut rendah (dekat dengan bentuk monopoli) (Buzzelli, 2001).

Cara yang digunakan untuk melihat hambatan masuk adalah dengan menggunakan skala ekonomis melalui output perusahaan yang menguasai pasar lebih dari 50 persen. Menurut Comanor dan Wilson (1967), MES yang lebih besar dari 10 persen menggambarkan hambatan masuk yang tinggi pada suatu industri. Nilai MES yang tinggi tersebut dapat menjadi penghalang bagi masuknya pedagang baru.

Berdasarkan perhitungan didapatkan nilai MES secara keseluruhan diatas 10\%. Hasil ini menunjukkan bahwa hambatan masuk yang tinggi pada suatu pasar komoditi Kota Tarakan, dimana pada skala ekonomi yang semakin besar akan semakin sulit bagi pedagang baru untuk masuk ke industri tersebut.

Makin terbatas pedagang besar dan pengecer untuk suatu produk dan seamakin banyak pesaing yang telah memanfaatkan saluran distribusi ini, akan semakin berat usaha untuk memasuki industri. Barrier to entry dari sisi jaringan distribusi semakin besar jika perusahaan-perusahaan lama memiliki hubungan erat dengan jaringan distribusinya. Seringkali hambatan-hambatan ini memaksa perusahaan-perusahaan yang akan masuk dalam industri harus membuat jaringan distribusi baru.
Sementara itu, analisis kinerja industri dilakukan dengan menggunakan analisis Price - Cost Margin (PCM). berdasarkan hasil perhitungan, mayoritas memiliki nilai PCM 80 - $100 \%$, hanya komoditi Daging Ayam Ras saja yang memiliki nilai PCM rendah yaitu sebesar $0,367 \%$. PCM biasanya diambil sebagai indikator kekuatan pasar karena semakin besar margin, semakin besar perbedaan antara harga dan biaya marjinal. PCM tergantung pada elastisitas permintaan yang ada di pasar. Nilai CR4 akan mempengaruhi PCM dengan arah yang sama. Nilai positif terlihat dari CR4 dan PCM. Oleh karena itu tingkatan konsentrasi akan mempengaruhi peningkatan PCM atau sebaliknya. Rata-rata PCM perusahaan empat teratas lebih besar dibandingkan nilai PCM perusahaan non empat besar hal ini terjadi karena pangsa pasar empat perusahaan teratas tinggi.

\section{SIMPULAN}

Hasil analisis menunjukkan bahwa pasar komoditas pangan cabe merah, cabe rawit beras, daging ayam ras segar, ikan bandeng dan telur ayam ras di Kota Tarakan masuk pada kategori struktur pasar very high oligopoly, hal ini ditunjukkan pada rasio konsentrasi pasar yang tinggi (mendekati angka 1). Hal ini didukung dengan nilai Minimum Efficiency Scale yang 
tinggi. Dimana barrier to entry pada pasar komoditas tersebut juga tinggi.

Dari hasil penelitian tersebut, disarankan agar pemerintah selaku decision maker dapat menerapkan kebijakan merger pada pasar komoditas pangan tersebut. Mengingat komoditas tersebut merupakan beberapa komoditas pangan tertinggi di Kota Tarakan. Selain itu, monitoring dan evaluasi secara periodik terhadap pasar akan menyebabkan pasar menjadi lebih kompetitif.

\section{DAFTAR PUSTAKA}

Arsyad, Lincolin, \& Kusuma, Stephanus Eri. 2014. Ekonomika Industri Pendekatan Struktur Perilaku dan Kinerja, UPP STIM YKPN, Yogyakarta.

Buzzelli, Michael. 2001. Firm size structure in North American housebuilding: persistent deconcentration, 1945 - 98, Environment and Planning A, 33, issue 3, p. 533-550, https://EconPapers.repec.org/ RePEc:pio:envira:v:33:y:200 1:i:3:p:533-550.

Comanor, W.S. and Wilson, T.A. 1967 Advertising, Market Structure and Performance. The Review of Economics and Statistics, 49, 423-440.

Chirwa, Themba G., \& Odhiambo, Nicholas $\quad$ M. 2016. Macroeconomic
Determinants Of Economic Growth: A Review Of International Literature. South East European Journal of Economics and Business Volume 11 (2) 2016, 33-47 DOI: $10.1515 /$ jeb-2016-0009. Cramer. 2009. Agriculture Economics and Agribusiness. John Willey and Son. New York.

Cristea, G. 2014. Analysis And Planning Of Regional Development-Contextual Variables To Develop A Model For Monitoring Financial Indicators At Regional Level. https://www.semanticscholar. org/paper/Analysis-AndPlanning-Of-RegionalVariables-To-A-AtCristea/81bfa941e4cf47e597 6267a707eff $22 d 204 d 1758 ? p 2$ $d f$.

Curry, B., \& George, K. 1983. Industrial Concentration: A Survey. The Journal of Industrial Economics, 31(3), 203-255. doi:10.2307/2097885.

Gavin, William T. and Rachel J. Mandal. "Predicting Inflation: Food for Thought." The Regional Economist Federal Reserve Bank of Saint Louis. January 2002. http://www.stls.frb.org/public ations/re/2002/a/pages/leadarticle.html. 
Hoskins, Colin., dkk. 2004. Media Economics:

Applying

Economics to New and

Traditional Media. Sage

Publications. Inc., California.

Hu, M., Zhang, D., Ji, Q., \& Wei, L. 2020. Macro factors and the realized volatility of commodities: A dynamic network analysis. Resources Policy, 68, 101813. https://doi.org/10.1016/j.reso urpol.2020.101813.

Kadir, Syamsurijal Abdul, dkk. 2020.

Structure, Conduct and Performance of the Coffee Processing Industry in Palembang and Pagar Alam Cities. Advances in Economics, Business and Management Research, volume 142.

Kuncoro, M. 2007. Ekonomi Industri Indonesia: Menuju Negara Industri Baru 2030. Yogyakarta: Andi.

Liebowitz, S. 1982. What Do Census Price-Cost Margins Measure? The Journal of Law \& Economics, 25(2), 231246. Retrieved October 23, 2020, from http://www.jstor.org/stable/72 5257.

Mason, E.S. 1939 Price and Production Policies of Large Scale Enterprises. The American Economic Review, 29, 61-74.
Mishkin, Frederic S. 1984. The Causes of Inflation. https://www.kansascityfed.or g/publicat/sympos/1984/S84m ishk.pdf.

Mishra, P. \& Vikas. 2010. Structure, conduct and performance in Indian pharmaceutical industry: A simultaneous equations investigation. Review of Development and Change, 15(1), 69-99.

Panagiotou, G. 2006. The Impact of Managerial Cognitions on the Structure-

ConductPerformance (SCP) Paradigm: A Strategic Group Perspective. Management Decision. 44: 423 - 441.

Wirth, Michael O. \& Bloch, Harry. 1995. Industrial Organization Theory and Media Industry Analysis, Journal of Media Economics, 8:2, 15-

26, DOI: $10.1207 / \mathrm{s} 15327736$ me0802_3.

Yoeti, Oka A, 2008. Perencanaan dan Pengembangan Pariwisata. Pradnya. Paramita: Jakarta 